\title{
Kultur og helse i HUNT - En metodeevaluering
}

\author{
Jostein Holmen $^{1}$, Camilla Nguyen ${ }^{2}$, Odd Håpnes ${ }^{3}$, Vegar Rangul ${ }^{1,4}$ og Geir Arild Espnes ${ }^{2}$ \\ 1) HUNT forskningssenter, Institutt for samfunnsmedisin, Det medisinske fakultet, NTNU, Norges teknisk- \\ naturvitenskapelige universitet, Levanger \\ 2) Senter for helsefremmende forskning, NTNU, Norges teknisk-naturvitenskapelige universitet, Trondheim \\ 3) Nasjonalt kompetansesenter for kultur, helse og omsorg, Levanger \\ 4) Avdeling for helsefag, Nord universitet, Levanger \\ Korrespondanse: Jostein Holmen, HUNT forskningssenter, Forskningsvegen 2, 7600 Levanger \\ E-post: jostein.holmen@ntnu.no Telefon: 97567869 (m) 74075183 (k)
}

\begin{abstract}
SAMMENDRAG
Flere studier har indikert at det er sammenheng mellom kulturdeltagelse og helse, men mange av studiene har vesentlige svakheter. Befolkningsstudier med et stort antall deltagere har flere fordeler, bl.a. er det mulig å kontrollere for konfunderende faktorer. Men i slike undersøkelser må antall spørsmål ofte begrenses, og det kan derfor stilles spørsmål ved hvor presis og relevant informasjonen blir. Ved HUNT3 (2006-08) ble to spørsmål om kulturdeltagelse inkludert: «Hvor mange ganger har du i løpet av de siste 6 måneder vært på/i: Museum, kunstutstilling/konsert, teater, kino/kirke, bedehus/idrettsarrangement", og «Hvor mange ganger har du løpet av de siste 6 måneder selv drevet med: Foreningsvirksomhet/musikk, sang, teater/menighetsarbeid/friluftsliv/dans/trening, idrett». Målet med denne studien var å undersøke hvordan spørsmålene ble oppfattet og tolket. Var informasjonen relevant til bruk i en epidemiologisk studie som HUNT? Det ble gjennomført tre fokusgruppeintervjuer med til sammen 17 deltakere i alderen 20 til 80 år. Flertallet hadde høyere utdanning. Tema som gikk igjen ble gruppert i kategorier, som bestod av beskrivelser over informantenes synspunkter og meninger. Hovedinntrykket fra fokusgruppeintervjuene var at informantene mente at spørsmålene i HUNT3 ga et grovt estimat på kulturaktivitetene i befolkningen. Vår konklusjon er at spørsmålene var tilstrekkelig presise til å bruke i analyser på gruppenivå.
\end{abstract}

This is an open access article distributed under the Creative Commons Attribution Licence, which permits unrestricted use, distribution, and reproduction in any medium, provided the original work is properly cited.

\section{INNLEDNING}

I folkehelsearbeidet er det økende interesse for å finne gode helsefremmende metoder, og sammenhengen mellom kultur, kulturdeltagelse og helse er et av de områdene som mange er opptatt av [1-3]. Men forskningsfeltet er ennå ungt. Det er gjennomført to kunnskapsoversikter i Norge som belyser sammenhenger mellom kulturdeltakelse og helse og kulturelle virkemidler i behandling og folkehelsearbeid $[4,5]$. Undersøkelser indikerer at aktiv og systematisk kulturdeltakelse kan øke livslengden [6], redusere forekomsten av demens [7] og gi økt livskvalitet [8]. Sang, musikk og andre kulturuttrykk har få bivirkninger og er egnet til å kombineres med medikamentell og kirurgisk behandling, og med andre miljøtiltak [9]. Integrering av kulturelle tiltak i helsevesenet kan gi oppmuntring til pårørende og bedre ansattes tilfredshet $\mathrm{i}$ arbeidssituasjonen $[10,11]$.

Det er alltid betydelige metodiske utfordringer ved slike studier. Mange studier er tverrsnittstudier som ikke kan si noe som årsaksforhold. Ofte er antallet deltagere relativt lavt, og seleksjon er dessuten en utfordring, da det oftest ikke er tilfeldig hvem som deltar i slike studier. Sosioøkonomi er en viktig konfunderende faktor, etter som de med høy utdanning og inntekt oftere deltar i kulturaktiviteter, samtidig som de også har bedre helse enn de som har mindre utdanning og lavere inntekt [12]. Definisjonen av begrepene kultur og kulturdeltagelse kan variere fra studie til studie, og det er brukt ulike helsemål, slik at det ikke er lett å sammenlikne resultatene.

Ved befolkningsundersøkelser, dvs. innsamling av helsedata fra et stort antall personer, kan en omgå noen av disse utfordringene. Etter som utvalget deltagere er større, er representativiteten ofte bedre, det er lettere å kontrollere for sosioøkonomi og andre konfunderende faktorer, og en kan studere kjønns- og aldersgrupper for seg. Ved å sammenstille data mot helseregistre som Kreftregisteret, Dødsårsaksregisteret og andre, er det også mulig å studere effekten av kulturdeltagelse på sykelighet og dødelighet. Ved den tredje runden av Helseundersøkelsen i Nord-Trøndelag (HUNT3, 200608) [13] ble spørsmål om kulturdeltagelse inkludert i et spørreskjema (skjema 2) som ble utlevert ved frammøte og innsendt $\mathrm{i}$ posten, og ca. 51000 personer $(54,1 \%)$ svarte på spørsmålene (Figur 1) [14]. Det ble demonstrert at kulturdeltagelsen var svært ulik i ulike kommuner i Nord-Trøndelag, noe som i ettertid førte til at fylkeskommunen økte de økonomiske rammene på 1 mill. kroner for å styrke Den kulturelle skolesekken i enkelte kommuner, nettopp for å utjevne denne skjevheten (personlig kommunikasjon, tidl. fylkeskultursjef R. Kvalø) [15]. Data fra HUNT3 viste at de som var kulturelt aktive opplevde bedre helse, var mer tilfreds med livet sitt og erfarte mindre angst og depresjon [12].

Definisjonen av kulturdeltagelse er imidlertid ikke enkel, særlig når spørsmålene skal inkluderes $i$ et spørreskjema som i HUNT. Også ved HUNT3 var det 
Tabell 1. Oversikt over alder, kjønn og utdanningsnivå til utvalget i undersøkelsen. Her er det brukt fiktive navn.

\begin{tabular}{|c|c|c|c|c|c|}
\hline \multicolumn{2}{|c|}{ FG 1 (20-30 år) } & \multicolumn{2}{|c|}{ FG 2 (40-60 år) } & \multicolumn{2}{|c|}{ FG 3 (70-80 år) } \\
\hline Navn/alder & $\begin{array}{l}\text { Utdanning } \\
\text { Høgskole/ } \\
\text { Universitet }\end{array}$ & Navn/alder & $\begin{array}{l}\text { Utdanning } \\
\text { Høgskole/ } \\
\text { Universitet }\end{array}$ & Navn/alder & $\begin{array}{l}\text { Utdanning } \\
\text { Høgskole/ } \\
\text { Universitet }\end{array}$ \\
\hline Mia, 21 år & $<4$ år & Tove, 41 år & $>4$ år & Liv, 70 år & $<4$ år \\
\hline Thomas, 24 år & $<4$ år & Berit, 50 år & $>4$ år & Amalie, 72 år & $<4$ år \\
\hline Henrik, 25 år & $<4$ år & Sissel, 53 år & $>4$ år & Vibeke, 75 år & $>4$ år \\
\hline Sander, 26 år & $<4$ år & Astrid, 54 år & $>4$ år & Sissel, 78 år & Handelsskolen \\
\hline $\begin{array}{l}\text { Ørjan, } 26 \text { år } \\
\text { Nils 26 år }\end{array}$ & $\begin{array}{l}>4 \mathrm{ar} \\
>4 a ̊ r\end{array}$ & Irene, 58 år & $>4$ år & Sigurd, 77 år & $\begin{array}{l}>4 \mathrm{ar} \\
>4 \mathrm{ar}\end{array}$ \\
\hline
\end{tabular}

stor konkurranse mellom ulike forskergrupper om å få plass til «sine» spørsmål. Etter som det er begrenset hvor store spørreskjemaene kan være, var mange forskergrupper nødt til å redusere på omfanget av spørsmål som de primært ønsket å ha med. Det ble derfor inngått mange kompromisser, der en i stedet for et detaljert sett av spørsmål ble nødt til å velge ut noen få av de mest sentrale spørsmålene innen temaet. En norsk/svensk forskergruppe av fagpersoner med bakgrunn i kulturarbeid og medisin/epidemiologi utarbeidet de endelige spørsmålene (Figur 1), da det ikke fantes relevante spørsmålssett fra tidligere studier, verken norske eller internasjonale. Spørsmålet som i neste omgang melder seg, er hva som faktisk måles. Målet med denne artikkelen var derfor å studere presisjon og relevans av spørsmålene om kulturdeltagelse i HUNT3. Hvordan blir spørsmålene tolket? Hva er styrkene og svakhetene ved den informasjonen som er samlet inn med metoden som ble brukt i HUNT3? Varierer disse oppfatningene mellom aldersgruppene? Er informasjonen relevant til bruk i en epidemiologisk studie som HUNT3?

\section{Metode OG MATERIALE}

Fokusgrupper. Datamaterialet ble samlet inn ved hjelp av tre fokusgruppeintervjuer [16] i perioden oktoberdesember 2015. Deltakerne ble rekruttert via nettverk og «snøballmetoden». Fokusgruppe 1 (FG1) var i alderen 20-30 år, fokusgruppe 2 (FG2) i alderen 40-60 år, og fokusgruppe 3 (FG3) i alderen 70-80 år. Til sammen 17 personer (10 kvinner og 7 menn) mellom 21-78 år deltok (gjennomsnittsalder 50 år). Flertallet hadde høyere utdanning (Tabell 1).

Informantene fikk tilsendt en kopi av de to kulturspørsmålene på epost i forkant av fokusgruppene (Figur 1). De fylte ut spørsmålene ved starten av fokusgruppen, og dette dannet grunnlaget for gruppediskusjonen. Det ble ikke lagt vekt på selve svarene, da vi var mer opptatt av deltakernes oppfatning og tolkning av spørsmålene. En semistrukturert intervjuguide ble benyttet under fokusgruppediskusjonene. Spørsmålene i guiden var dels rettet mot informantenes oppfatninger og tolkninger av spørsmålene og dels mot deres egne kulturaktiviteter, og de inneholdt ingen etisk problematiske spørsmål. Informantene fikk anledning til å diskutere spørsmålene, de fikk utdype hverandres synspunkter samt dele sine egne meninger på utsagn de var uenig om. Fokusgruppene varte rundt en time og samtalen ble tatt opp på lydbånd.

Dataanalyse. Lydopptakene ble transkribert ordrett og grundig gjennomlest. Analysen av datamaterialet fulgte retningslinjene innen Grounded theory [17]. Den transkriberte informasjonen ble overført til det kvalitative programmet OpenCode (versjon 4.0.3). Meningsinnholdet fra datamaterialet ble først sett i sin helhet og kodet med bestemte nøkkelord. Tema som gikk igjen ble gruppert $\mathrm{i}$ kategorier, som bestod av beskrivelser over informantenes synspunkter og meninger. Datamaterialet fra denne undersøkelsen er anonymisert. Der det er brukt sitater er disse oppgitt med fiktive navn. Vi har valgt å inkludere uttalelser som viser flere aspekter ved et tema og ikke bare den vanligste dimensjonen.

\section{KULTUR/LIVSSYN}

(11) Hvor mange ganger har du i løpet av de siste 6 måneder vært på/i: (Sett ett kryss pr. linje)

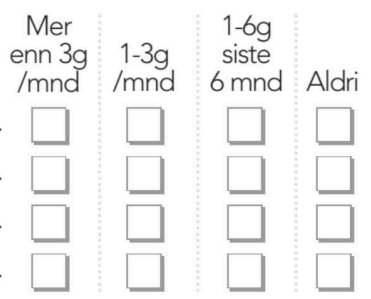

Museum, kunstutstilling.............

Konsert, teater, kino...................

Kirke, bedehus

Idrettsarrangement

2. Hvor mange ganger har du i løpet av de siste 6 måneder selv drevet med:

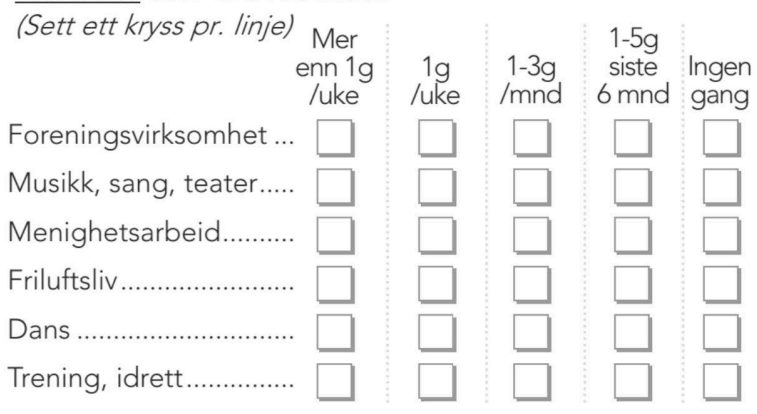

Figur 1. Spørsmålene om kulturdeltagelse i HUNT3. Spørsmål om livssyn var inkludert i samme spørsmålsbolken, derfor overskrifta «Kultur/livssyn». Dette var også grunnen til at «kirke/bedehus» var inkludert i spørsmål 11 og «menighetsarbeid» i spørsmål 12. 


\section{RESULTATER}

\section{Spørsmål 11}

Informantene mente at spørsmål 11 var lett å forstå, og de fleste tolket det slik at det ble spurt om plasser man oppsøker for å oppleve noe sammen med andre.

«For altså, det første spørsmålet er jo noe du oppsøker som handler om noe som andre arrangerer. Det andre er du mer aktiv i på en måte.»

(Liv, 70 år)

Det var likevel flere som mente at spørsmålet var litt for generelt i forhold det de opplevde som «kultur». «Hvis du ser rundt på det så er det helt greit. Men hvis en begynner liksom og spesifiserer og går ned på det enkelte arrangementet hva det (er). Så er det jo klart at det er veldig mye som kunne ha kommet inn her.»

(Vibeke, 75 år)

Noen var usikre på hva som lå i begrepet «kunstutstilling».

«Altså 'kunstutstilling' er jo litt diffus begrep. Men personlig så er jeg litt interessert i frimerker og er stadig på frimerkeutstillinger, og det synes jeg er kunst da for det er jo veldig mye fine frimerker å se på. Så det er litt tvil om det kommer inn under 'kunstutstilling'.»

(Sigurd, 77 år)

Mange mente at tidsperspektivet «i løpet av de siste seks måneder» var for kort.

«Nei det spørs jo hva dere vil kartlegge, de siste 6 månedene eller at dere vil se hva folk gjør sånn til vanlig. Så når det begrenser seg til de siste 6 månedene så begrenser det litt av svarene synes jeg.»

(Sissel, 53 år)

Flere mente at dette alternativet ikke fanget opp sesongvariasjonen av aktiviteten deres i løpet av det siste året. En del mente at de ville ha svart annerledes avhengig av når på året det ble spurt. Spesielt de fra FG3 (70-80 år) ga klart uttrykk for at dette alternativet ikke var særlig tilpasset deres aldersgruppe. De forklarte at deres aktiviteter, spesielt konserter, teater og kino, er sterkt påvirket av årstidene, slik at de vanligvis er mer passive på sommeren sammenlignet med resten av året.

«Vi går jo på konsert fra høsten og frem til mai. Ja vi var vel på noe sånn sommerkonserter sånn av og til men det er klart at det er veldig forskjell fra årstid til årstid.»

(Trond, 78 år)

En av informantene opplevde ikke dette som problematisk, da hun heller beregnet dette ut fra hvor ofte hun benyttet seg av dette kulturtilbudet $\mathrm{i}$ gjennomsnitt i stedet for de siste 6 måneder.

«Men på de to første kolonnene da mer enn per måned. Så tenkte jeg litt sånn gjennomsnittlig. Så det hadde ikke noe å si for meg om det nå er høst eller vår eller sommer var det jeg tenkte, ja hva gjør jeg da gjennomsnittlig i måneden.»

(Vibeke, 75 år)
I tillegg fremhevet de fra FG1 (alder 20-30 år) at svaralternativet «1-6 i løpet av de siste 6 mnd» gjør det vanskelig å skille mellom hyppigheten på de enkelte kategoriene, f.eks. kirke, konsert, teater og kino. I samtlige fokusgrupper ble det nevnt at det burde være et skille mellom aktivitetene i kategorien «konsert, teater, kino», da de betraktet noen av aktivitetene som mer «høykultur».

«Det er jo litt mer finkultur $i$ de der konsertene enn med kino for eksempel.»

(Sigurd, 77 år)

De fleste følte at kirke/bedehus ikke passet inn under temaet kultur. De forsto ikke hvorfor akkurat «kirke/ bedehus» har blitt inkludert som en egen kategori, noen mente at det finnes mange andre kulturaktiviteter som de følte kunne ha blitt inkludert i kategoriene $i$ tillegg til kirke. Flere mente at det føltes unaturlig/ikke riktig å sette «aldri» i svar rubrikken, siden de følte at det ga et inntrykk av at de «aldri» har drevet med disse aktivitetene «noen gang i sitt liv». Det viste seg at noen av dem hadde oversett at dette gjaldt «aldri i løpet av de siste 6 måneder». Selv om denne misforståelsen ble oppklart under gruppediskusjonen, syntes de likevel at det ikke føltes riktig å krysse av på «aldri». «... For hvis det var arrangement som du kanskje er $i$ 1-2 ganger $i$ året så kan du glippe imellom også det føles liksom feil å si «aldri» men det er ikke sant å si 1-6 (i de 6mnd.) heller.»

(Berit, 50 år)

Noen av informantene fortalte at de hadde vært på steder der det foregikk flere aktiviteter. Dette førte til en diskusjon mellom informantene om hva de ville ha svart hvis det var aktiviteter som kunne passe inn under flere av kategoriene.

«Jeg var på en konsert for to eller tre uker siden som $v a r$, det var en konsert $i$ en kirke hvor det samtidig var en kunstutstilling, så det var egentlig sånn ... Jeg kryssa av på alle de tre (kategoriene) da ... Det var fordi altså jeg var jo tross alt i kirken, jeg var tross alt på konsert og det var tross alt en kunstutstilling der så men det ja jeg gikk dit på grunn av konserten så jeg vet ikke om jeg skal ta utgangspunkt hva jeg selv, mitt mål med å dra dit eller hva jeg faktisk holder på med?»

(Ørjan, 26 år)

Det var ulike synspunkter på hvordan de ville ha klassifisert disse aktivitetene i spørreskjemaet. Noen ville ha krysset av på alle de nevnte aktivitetene på den aktuelle plassen, mens andre bare ville ha krysset av på den aktiviteten som de dro dit for. Noen syntes det var vanskelig å klassifisere aktiviteter hvor man både var tilskuer og deltager.

«Ja men for der har jeg et spørsmål, for jeg har jo vaert med på 'Idrettsarrangement', jeg er der men jeg deltar og.»

(Tove, 41 år)

Under diskusjonen med aldersgruppen 70-80 år, var det en kvinne som fortalte at hun bruker å delta på 
allsang i forbindelse foreningsarrangementer. Men hun var usikker på om allsang er ligger under kategorien «musikk, sang, teater».

«Jeg ville ha krysset av at jeg hadde sunget, du er sammen med en del mennesker og synger regelmessig. Så er du liksom ikke noe mindre 'finkulturell' altså sangkor på en måte.»

De fleste av informantene var enig $i$ at allsang tilhørte kategorien «musikk, sang, teater». De mente at aktivitetene under kategorien «sang» måtte være organisert og noe man har drevet med selv.

\section{Spørsmål 12}

I følge informantene var spørsmål 12 også lett å fylle ut. De oppfattet at det her ble spurt om hvilke fritidsaktiviteter man aktivt driver med, mens det forrige spørsmålet gjaldt aktiviteter der man var tilskuer. En del var usikker på hva som regnes som «foreningsvirksomhet», og det resulterte $i$ at noen valgte å oppgi at de ikke hadde drevet med dette. Når vi spurte om hva de trodde lå $\mathrm{i}$ dette begrepet, mente noen at foreningsvirksomhet var når man hadde styreverv $\mathrm{i}$ foreninger, mens andre mente det var tilstrekkelig at man var aktiv medlem som deltok i møter. Som eksempler ble nevnt studentforeninger, politiske partier, Naturvernforbundet, husmorlaget, organisasjoner, dugnad og sameie.

«Jeg synes ordet foreningsvirksomhet er litt for upresist altså, er du aktiv eller passiv? går du på historielag, på foredrag og på møte men ellers ikke yter noe spesielt altså sånn foreningsvirksomhet ... Er det nok at du er medlem?»

(Trond, 78 år)

«Jeg tror jeg ser veldig mye enklere på verdenssituasjonen. Fordi jeg så på det her 'foreningsvirksomheten' som om jeg selv var aktiv og gikk, og medlemmer her og der.»

(Vibeke, 75 år)

I likhet med spørsmål 11 mente informantene at tidsperspektivet «de siste 6 måneder» ikke ga et godt bilde av kulturaktivitetene deres.

«Jeg var med og startet opp sånn landsklubb for studenter $i$ Trondheim, men jeg ikke holdt med det $i$ de siste 6 månedene. Så tokjeg 'ingen gang' da, men (jeg) var jo med og startet det hele da. Det ble 'ingen gang' på det da, selv om jeg har vart aktiv medlem der i lang tid nå ... Nå gir jo jeg inntrykk av at jeg ikke har vart med på noe foreningsvirksomhet i det hele tatt, men jeg har jo i blant.»

(Sander, 26 år)

Informantene følte at tidsperspektivet på seks måneder ikke var så relevant, siden aktivitetene deres var veldig varierende. De mente at tidsperspektivet burde heller utvides til 12 måneder. Noen av informantene stusset over at det fantes en egen svarkategori for dans. Etter deres mening virket det unaturlig at dans hadde en egen kategori i motsetning til «musikk, sang, teater» som hadde en felles kategori. Ved at «dans» står som en egen kategori, kunne dette ifølge dem mistolkes som «uorganisert dans».

«Da synes jeg 'dans' ble helt merkelig for meg. For hva er uorganisert dans liksom?»

(Astrid, 54 år)

Ulik skala. Noen ble litt forvirret av at spørsmål 12 ikke hadde samme skala som spørsmål 11. De mente at det burde være lik skala-inndeling på begge spørsmålene, siden man hadde blitt vant til inndelingen på det forrige spørsmålet.

«Jeg er enig, synes det er alltid lettere å forholde seg til en hvis du har en fast format så går det fortere å svare ... folk blir ikke uinteressert og begynner å krysse vilt etter en stund.»

(Nils, 26 år)

Informantene fra FG3 (70-80 år) hadde ulike synspunkter på hva de så på som «friluftsliv». Noen mente at dette inkluderte turer utendørs mens andre mente at «friluftsliv» var når man gikk på tur i fjellet.

«For jeg forstår det jo sånn at det er viktig for dere å fange opp alle typer folk. Da tenker jeg for å fange opp alle typer folk, så er det litt sånn så lenge de er $i$ bevegelse og går tur, og vi går tur en gang eller to $i$ uken. Så er det jo friluftsliv i den forstand. Men du trenger liksom ikke å ha på deg ryggsekken og opp på en topp.»

(Astrid, 54 år)

Informantene fra FG2 (40-60 år) kom med forslag om å inkludere begrepet «tur» sammen med «friluftsliv»» kategorien. Den ene informanten syntes det var spesielt vanskelig å klassifisere dans og friluftsliv. Flere mente at enkelte friluftsaktiviteter som f.eks. jogging i marka, var mer over mot kategorien «trening». Når det gjaldt spørsmål om det var noen aktiviteter som manglet i spørreskjemaet, ble det blant annet nevnt matlaging, festivaler, fotografi, byvandring, i tillegg til foredrag/kurs, litteratur, bibliotek og internett - som noen nevnte var en form for «kulturell opplysning». En del betraktet sosiale aktiviteter som f.eks. kafé, restaurant og pub som viktige kulturelle opplevelser.

«Jeg kunne godt tenkt meg å ha med et punkt som du sier kursvirksomhet på den der jeg altså. For det er utrolig mange eldre som går på mange slags kurs.»

(Trond, 78 år)

Spesielt de i aldersgruppen 70-80 år etterspurte en kategori for «kursvirksomhet», siden de ofte drar på f.eks. foredrag og språkkurs.

\section{DISKUSJON}

Denne evalueringsstudien viste at informantene syntes det var greit å svare på spørsmålene, og de mente at spørsmålene ville gi et generelt bilde av kulturaktivitetene blant folk flest. De fleste oppfattet også at spørsmål 11 (museum, kunstutstilling/konsert, teater, kino/ kirke, bedehus/idrettsarrangement) omfatter «passiv» 
deltagelse, mens spørsmål 12 (foreningsvirksomhet/ musikk, sang, teater/ menighetsarbeid/friluftsliv/dans/ trening, idrett) omfatter «aktiv» deltagelse. Under gruppediskusjonene kom det flere kommentarer:

- Informantene tolket spørsmålene noe ulikt, bl.a. savnet flere kategorier, slik at de kunne få rapportert bedre det som passet den enkelte. Foredrag og sosiale aktiviteter i samvær med andre var blant de aktivitetene de følte manglet.

- De mente at tidsintervallet på seks måneder var for kort, da det ikke ga et riktig bilde av kulturaktivitetene deres etter som disse varierte en god del $\mathrm{i}$ løpet av året. De ville heller brukt et tidsintervall på 12 måneder.

- Flere mente at «kirke/bedehus» ikke passet inn under temaet kultur.

- Det var noe ulike oppfatninger i de ulike aldersgruppene.

Hovedinntrykket er at informantene mente at spørsmålene ga et generelt inntrykk av kulturaktivitetene blant folk flest, men at de ønsket mer detaljerte spørsmål som ville passe bedre til den enkelte. Ulike tolkninger kan selvsagt gi upresis informasjon.

En svakhet ved studien er at utvalget besto i stor grad av personer med høy utdanning, og de aller fleste var trolig mer kulturelt aktive enn gjennomsnittet $i$ befolkningen. Det ville vært en styrke hvis det hadde vært flere informanter på tvers av samfunnslag og en jevnere kjønnsfordeling i fokusgruppe 1 og 2. Kanskje dette kunne fremkalle andre synspunkter. Kulturspørsmålene i HUNT3 ble besvart av 54,1\% av de inviterte, og det er tidligere vist at de som deltok hadde gjennomgående bedre helse enn de som ikke deltok [18]. Denne seleksjonen vil redusere generaliseringsverdien av HUNT3-dataene, men er ikke vesentlig for tolkningen av vår evalueringsstudie.

Hovedspørsmålet er om den informasjonen som kommer fram ved bruk av disse spørsmålene er tilstrekkelig presis og relevant til bruk $\mathrm{i}$ en epidemiologisk studie som HUNT. Etter som det alltid er knapt om plassen på spørreskjemaene ved undersøkelser som HUNT, er det ikke overraskende at informantene etterlyste mer detaljerte svarkategorier som passet bedre til dem personlig. De var noe ulike tolkninger av enkelte av spørsmålene, og tilfeldige individuelle variasjoner i tolkningen av spørsmål vil alltid være en feilkilde. Men da analysene alltid gjøres på gruppenivå er dette som regel ingen stor svakhet i materialet. Dersom det er systematiske feiltolkninger, er det alvorligere, men i disse fokusgruppeintervjuene fant vi ingen holdepunkter for systematiske feiltolkninger.

Etter som det ble spurt om kulturaktiviteter bare siste seks måneder, mente informantene at de ikke fikk rapportert alle sine aktiviteter, og mente at et tidsintervall på 12 måneder ville passet bedre med sesongvariasjonene. Dette kan føre til informasjons-bias. Under de statistiske analysene i HUNT3 ville det trolig likevel ikke bety mye, da datainnsamlingen ved HUNT3 foregikk året rundt for alle grupper, slik at på gruppenivå vil en uansett få registrert sesongvariasjonene $i$ aktivitetene.

Spørsmålet om besøk i kirke/bedehus var en del av spørsmålssettene om livssyn, som på spørreskjemaet var plassert nedenfor spørsmålene om kulturaktiviteter. Informantene mente at dette spørsmålet ikke hørte med under kulturaktiviteter, og derfor ikke passet her. Spørsmålet om besøk i kirke/bedehus var heller ikke ment som kulturaktivitet, og det er gjort en egen valideringsstudie av livssynsspørsmålene [19].

Etter som skjemaene i en studie som HUNT skal fylles ut av flere titusen personer i alle samfunnslag og i alle aldre, må spørsmålene begrenses i omfang. Dette vil nødvendigvis gå utover presisjonen, slik det også er demonstrert $\mathrm{i}$ denne studien. Det er heller ikke sjelden at en i ettertid oppdager uheldige formuleringer. Det blir da ofte diskusjon om en skal reformulere spørsmålet ved neste runde av HUNT eller om en skal fortsette med en ikke-optimal formulering. Dersom en skal studere endringer over tid, er det nødvendig at formuleringene er identiske. Dersom en forandrer formuleringen, blir det ofte svært vanskelig, kanskje umulig, å sammenligne endringer over tid. Ofte er det derfor sterke argumenter for å beholde formuleringene selv om de ikke er optimale.

\section{KONKLUSJON}

Denne metodeevalueringen indikerer at spørsmålene om kulturdeltakelse i HUNT3 gir et grovt estimat på kulturaktivitetene i befolkningen. Med bakgrunn i det som kom fram gjennom fokusgruppeintervjuene er det grunn til å anta at de som fyller ut skjemaet stort sett greide å skille mellom «passiv» og «aktiv» deltagelse. På individnivå gir spørsmålene rom for ulike tolkninger, slik at presisjonen ikke er høy, men vi fant ingen indikasjoner på systematiske feiltolkninger. Dersom det ved seinere HUNT-undersøkelser er bedre plass på skjemaet, er det en fordel om spørsmålene presiseres bedre. Hvis ikke, er spørsmålene tilstrekkelig presise for å bruke i analyser på gruppenivå.

\section{REFERENCES}

1. St.meld. nr. 48 (2002-2003). Kulturpolitikk fram mot 2014.

https://www.regjeringen.no/no/dokumenter/stmeld-nr-48-2002-2003-/id432632/?ch=1\&q=, 2003.

2. St.meld. 25 (2005-2006). Mestring, muligheter og mening. Framtidas omsorgsutfordringer. https://www.regjeringen.no/no/dokumenter/stmeld-nr-25-2005-2006-/id200879/?ch=1\&q=, 2006.

3. NOU 2011:11. Innovasjon i omsorg. https://www.regjeringen.no/no/dokumenter/nou-201111/id646812/?ch=1\&q=, 2011. 
4. Knudtsen MS, Holmen J, Håpnes O. Hva vet vi om kulturdeltakelse og helse? Tidsskr Nor Laegeforen 2005, 125: 3418-3420.

5. Knudtsen MS, Holmen J, Håpnes O. Kulturelle virkemidler i behandling og folkehelsearbeid. Tidsskr Nor Loegeforen 2005, 125: 3434-3436.

6. Bygren LO, Konlaan BB, Johansson SE. Attendance at cultural events, reading books or periodicals, and making music or singing in a choir as determinants for survival: Swedish interview survey of living conditions. BMJ 1996, 313: 1577-1580.

7. Verghese J, Lipton RB, Katz MJ, Hall CB, Derby CA, Kuslansky G, et al. Leisure activities and the risk of dementia in the elderly. $N$ Engl J Med 2003, 348: 2508-2516.

8. Bowling A. Ageing well: quality of life in old age. Cambridge: Cambridge Univeristy Press, 2005.

9. Myskja A. Integrated music in nursing homes - An appoach to dementia care. Bergen: Universitetet i Bergen, 2012.

10. Gotell E, Brown S, Ekman S-L. The influence of caregiver singing and background music on vocally expressed emotions and moods in dementia care: a qualitative analysis. Int J Nursing Studies 2009, 46: 422-430.

11. Clift S, Camic P. The Oxford Textbook of Creative Arts, Health, and Wellbeing. International Perspectives on practice, policy and research. Oxford: Oxford University Press, 2015.

12. Cuypers K, Krokstad S, Holmen TL, Skjei KM, Bygren LO, Holmen J. Patterns of receptive and creative cultural activities and their association with perceived health, anxiety, depression and satisfaction with life among adults: the HUNT study, Norway. J Epidemiol Community Health 2012, 66: 698-703.

13. Helseundersøkelsen i Nord-Trøndelag (HUNT). http://www.ntnu.no/hunt, 2016.

14. Krokstad S, Langhammer A, Hveem K, Holmen T, Midthjell K, Stene T, et al. Cohort Profile: The HUNT Study, Norway. Int J. Epidemiol 2013;42 (4): 968-77.

15. Nord-Trøndelag fylkeskommune Fylkestinget. Økonomistrategi 2012-15. Sak $\mathrm{nr}$ 11/52. http://www.ntfk.no/bibliotek/saker/2011/FT/FT011052.htm, 2011.

16. Kvale S, Brinkmann S: Det kvalitative forskningsintervju (2. utg.). Oslo: Gyldendal Norsk Forlag, 2009.

17. Dahlgren L, Emmelin M, Winkvist A: Qualitative Methodology for International Public Health. Umeå: Umeå Universitet, 2007.

18. Langhammer A, Krokstad S, Romundstad P, Heggland J, Holmen J. The HUNT study: participation is associated with survival and depends on socioeconomic status, diseases and symptoms. BMC Med Res Methodol 2012, 12: 143.

19. Sørensen T, Lien L, Holmen J, Danbolt LJ. Distribution and understanding of items of religiousness in the Nord-Trøndelag Health Study, Norway. Mental Health, Religion and Culture 2012, 15: 571-585. 